\title{
Subjective satisfaction and objective electricity poverty reduction in Vietnam, 2008-2018
}

\author{
Minh Ha-Duong \\ CIRED, CNRS, Paris, France, and \\ Hoai-Son Nguyen \\ National Economics University, Hanoi, Vietnam
}

Electricity

poverty

reduction in

Vietnam

\begin{abstract}
Purpose - The authors estimate the reduction of electricity poverty in Vietnam. The essential argument is that human development is about subjective feeling as much as technology and income.

Design/methodology/approach - The authors use a self-reported satisfaction indicator as complementary to objective indicators based on national household surveys from 2008 to 2018.

Findings - In 2010, the fraction of households with access to electricity was over $96 \%$. However, over $24 \%$ declared their electricity use did not meet their needs. Since 2014, the satisfaction rate is around $97 \%$, even if $25 \%$ of the households used less than $50 \mathrm{kWh} /$ month. Today there is electricity for all in Vietnam, but electricity bills weigh more and more in the budget of households.

Practical implications - The subjective energy poverty measure allows better international statistics: unlike poverty or needs-based criteria, self-assessed satisfaction of needs compares across income levels and climates.

Social implications - Inequalities in electricity use among Vietnamese households decreased during the 2008-2018 period, but are not greater than inequalities in income, contrary to the findings of Son and Yoon (2020).

Originality/value - Engineering and econometric objectivist approaches dominate the literature on sustainability monitoring. Out of 232 sustainable development goal (SDG) indicators, only two are subjective. Yet the findings show that subjective indicators tell a different part of the story. Access is not grid building, but the meaningful provision of electricity to satisfy the needs.
\end{abstract}

Keywords Electricity, Poverty, Vietnam, Sustainable development goals, Indicators

Paper type Research paper

\section{Introduction}

The seventh United Nations sustainable development goal (SDG 7) is to "ensure access to affordable, reliable, sustainable and modern energy." In short, "affordable and clean energy"

\section{JEL Classification - Q41, Q48, Q56}

(C) Minh Ha-Duong and Hoai-Son Nguyen. Published in Fulbright Review of Economics and Policy. Published by Emerald Publishing Limited. This article is published under the Creative Commons Attribution (CC BY 4.0) license. Anyone may reproduce, distribute, translate and create derivative works of this article (for both commercial and non-commercial purposes), subject to full attribution to the original publication and authors. The full terms of this license may be seen at http://creativecommons. org/licences/by/4.0/legalcode

NHS provided the initial idea and the data, and HDM directed the research. The two authors contributed to the statistical analysis and writing. This work was started while the first author was a visiting professor at the Clean Energy and Sustainable Development Lab (CleanED/USTH). Early versions of this work were presented at the CIRED research seminar, the tenth Vietnam Economist Annual Meeting and the first online conference of the International Association of Energy Economists. The authors gratefully acknowledge comments from our colleagues Audrey Berry, Franck Nadaud, Nguyễn Trinh Hoang Anh and Rodica Loisel and anonymous reviewers. The authors declare no conflict of interest. 
FREP

1,1

is one of our overarching civilization goals this millennium. Statisticians usually measure progress toward SDG 7 using objective indicators based on electricity distribution and consumption data. We argue that objective indicators are not enough. Human development is an issue of subjective feeling as much as a question of technology or economics. Based on national household surveys, self-reported satisfaction indicators offer a complementary perspective to understand a society's energy poverty situation more fully.

Vietnam is a Southeast Asia country comprising almost 100 million people. The country's gross domestic product (GDP) per capita, purchasing power parity, was USD 8397 in 2019 (World Bank database, accessed 2021-05-22). The country's development has been highly successful in economic terms. In constant local currency, the GDP grew by $541 \%$ from 1986 to 2019. Table 1 provides details of the country's trajectory. Vietnam's rural electrification program is oft-cited as an outstanding success in providing energy access (Đoàn, 2010; Asian Development Bank, 2011). However, in the considerable academic literature on energy poverty, among the reports on China, India, Brazil and South Africa (Li, Pan, \& Wei, 2015; Sovacool, Mukherjee, Drupady, \& D’Agostino, 2011; Baltruszewicz, Steinberger, Ivanova, Brand-Correa, Paavola, \& Owen, 2021), we found few studies about Vietnamese households.

Lê (2020) investigated residential electricity demand in Vietnam using a different microdata source, the 2015 Vietnam Household Registration Survey. He found that demand is elastic to average and marginal prices and confirmed that income elasticity is positive. We examine residential demand from a different perspective - energy poverty - using different data: the Vietnam Households Living Standard Surveys (VHLSS) from 2008 to 2018.

Son \& Yoon (2020) examined the determinants of inequality in Vietnamese households' electricity consumption, using VHLSS data from 1993 to 2004. Inequality can be defined, at the population level, by how much the statistical distribution of consumption deviates from the uniform distribution. They found that (1) electricity consumption increased more than proportionally with income and (2) the inequality of electricity consumption was larger than income inequality. The grid expanded continuously from 1993 to 2004, increasing electricity access. Son and Yoon warned that increasing access could increase inequality as wealthier households benefited more from the opportunity. Those who cannot afford to buy electric appliances benefit less from rural electrification. Our analysis of recent data corroborates their first finding: Electricity consumption increased faster than income between 2008 and 2018. We do not confirm their second finding. In 2018, electricity

\begin{tabular}{|c|c|c|c|c|c|c|}
\hline Year & 2008 & 2010 & 2012 & 2014 & 2016 & 2018 \\
\hline Population (Thous. pers.) & 85,119 & 86,947 & 88,809 & 90,729 & 92,695 & 94,666 \\
\hline $\begin{array}{l}\text { GDP at constant } 2010 \text { prices, } \\
\text { trillion VND }\end{array}$ & 1,889 & 2,158 & 2,413 & 2,696 & 3,054 & 3,493 \\
\hline $\begin{array}{l}\text { GDP per capita, PPP constant } \\
2017 \text { USD }\end{array}$ & 4,628 & 5,089 & 5,574 & 6,098 & 6,767 & 7,586 \\
\hline $\begin{array}{l}\text { Consumer price index, base } \\
100 \text { in } 2007\end{array}$ & 123 & 144 & 186 & 206 & 213 & 228 \\
\hline $\begin{array}{l}\text { Share of population in urban } \\
\text { areas }\end{array}$ & $29.0 \%$ & $30.5 \%$ & $31.8 \%$ & $33.1 \%$ & $33.9 \%$ & $34.5 \%$ \\
\hline Electricity production, annual & $71.0 \mathrm{TWh}$ & 91.7 TWh & 115.1 TWh & 141.2 TWh & 175.7 TWh & $209.2 \mathrm{TWl}$ \\
\hline Electricity production, annual & $834 \mathrm{kWh}$ & $1,055 \mathrm{kWh}$ & $1,297 \mathrm{kWh}$ & $1,557 \mathrm{kWh}$ & $1,896 \mathrm{kWh}$ & $2,221 \mathrm{kWh}$ \\
\hline
\end{tabular}

Table 1.

Vietnam's economy and electricity conditions in 2008-2018
Note(s): Economic and political reforms launched in 1986 have transformed Vietnam from one of the world's poorest nations to a lower-middle-income country

Source(s): General Statistics Office, accessed 2021-02-08 and World Bank for GDP based on purchasing power parity (PPP) 
consumption inequality seemed comparable to or less than income inequality (see Supplementary Figure 5).

Analyzing the evolution of the energy consumption of Vietnamese households from 2004 to 2016, Nussbaumer, Bazilian, \& Modi (2012) found that "[e]lectricity poverty has decreased, but energy-cost poverty has increased." Our analysis vindicates these findings. We clarify and confirm the discrepancy between electricity poverty and electricity-cost poverty using recent data.

The paper is organized as follows. We contrast the objective and subjective perspectives used to observe electricity poverty in section 6 . Then we present the data and methods in section 10 before examining Vietnamese households' electricity consumption from 2008 to 2018 from three points of view in sections 11 through 17: the engineering perspective (grid access and kilowatts per hour consumed), the economic perspective (income and expenditures) and the subjective perspective (satisfaction with electricity consumption). Then we discuss the interactions between the three perspectives in section 20 . The findings highlight how much the subjective indicator complements objective engineering or economic indicators. We discuss the results and policy implications and compare them with other member states of the Association of Southeast Asian Nations (ASEAN), in section 8. We summarize the paper and conclude in section 9 .

\section{What is access to clean and affordable energy for all?}

The Sustainable Development Solutions Network (SDSN, 2015, pp. 137-140) defined four performance indicators that assess progress toward SDG 7 (ensure access to affordable, reliable, sustainable and modern energy for all): share of the population with access to modern cooking solutions (percentage; Indicator 50), the share of the population with access to reliable electricity, by urban and rural (percentage; Indicator 51), implicit incentives for low-carbon energy in the electricity sector (measured as USD/MWh or USD per ton avoided $\mathrm{CO}_{2}$; Indicator 52) and the rate of primary energy intensity improvement (Indicator 53).

Although all four dimensions of SDG 7 matter, we focus on the dimension measured by Indicator 51, access to reliable electricity. We distinguish three perspectives on access to electricity. The engineering perspective sees access as the presence of the distribution network. The economic perspective focuses on affordability. Finally, the subjective perspective focuses on whether users feel that their electricity needs are satisfied. We contend that the subjective perspective solves many problems found in the economic literature on energy poverty.

Atkinson (1987) explained that poverty can be seen as a concern about basic needs, which are multidimensional: food, housing and clothing. In this viewpoint, energy poverty can be seen as deprivation of the energy needs for survival. Energy-poor households cannot afford to fight cold in winter or heat in summer. How can we measure the magnitude of energy poverty in a given country? In the subjective perspective, this is straightforward: Use a survey asking whether the household's energy use met their needs in the previous month. The economic perspective is more complex. There are three approaches to defining and measuring energy poverty.

The first approach is to estimate "basic needs" directly by calculating the minimum energy services required for a household. Bravo, Mendoza, Legisa, Suárez, \& Zyngierman (1983), cited in He \& Reiner (2016), enumerated energy needs to prepare and preserve food and a water supply, for space conditioning, personal cleanliness, and recreation and social communication. Pachauri, Mueller, Kemmler, \& Spreng (2004) computed the power requirements for energy services of a five-member household such as "scooter $5 \mathrm{~km} /$ day", "Lighting, one electric bulb (5 h/day, $40 \mathrm{~W})$ " and "Lighting, 1-2 kerosene lamps".
Electricity poverty reduction in Vietnam 
FREP 1,1

This basic needs direct estimate approach is appropriate on a case-by-case basis, at the scale of communities, but not for international statistics. Different societies have different views on what kinds of energy services constitute basic needs. Needs vary with climate, region, household demographics and even ethnocultural habits (Pachauri, Mueller, Kemmler, \& Spreng, 2004). Asking experts about local conditions is open to subjectivity and lacks legitimacy.

The second approach sets up absolute thresholds for the total energy consumption regardless of the consumption components. Energy-poor households consume less than $X$ $\mathrm{kWh}$ per year, where $X$ depends on the country's economic conditions. Foster, Tre, \& Wodon (2000) defined the threshold as the average energy consumption of households whose expenditure per capita within $10 \%$ of the official poverty line.

This approach is convenient. A poverty line is readily available in every country. However, the underlying assumption that income-poor households are also energy-poor households is not always valid (Khandker, Barnes, \& Samad, 2012).

The third approach sets up relative thresholds. Energy-poor households are those spending more than $X \%$ of their income on energy bills. The Department of Trade and Industry (DTI, 2007) stated that a household is energy poor if the household spends more than $10 \%$ of its income on paying the energy bill, including electricity and fuel for heating and cooking, excluding transportation. This threshold was set out officially in the United Kingdom(UK) Fuel Poverty Strategy 2001, according to Hills' (2012) critical study. France also used this approach, according to the Observatoire National de la Précarité Énergétique (2016).

This approach is convenient. It assesses the magnitude of the energy affordability issue from national-scale statistics. Unfortunately, the approach has fatal flaws. The ratio is arbitrary; there are no universal norms for the share of electricity in a household budget. Moreover, many consumers with a relatively high energy bill are affluent households living large, while many poor households have a low energy bill because they use non-commercial biomass.

The three approaches to energy poverty reviewed above are based purely on energy quantities, monetary indicators, or their combination. They all come from an engineering or econometric approach. To fix their theoretical problems, researchers and practitioners have proposed more sophisticated objective approaches. Hills (2012) led the UK to replace the $10 \%$ of income criterion with a new definition under which households are considered fuel poor if (1) they have required fuel costs that are above the median level and (2) were they to spend that amount they would be left with residual income below the official poverty line. Econometric approaches based on electricity demand elasticity were explored by Khandker, Barnes, \& Samad, 2012 for energy poverty in Bangladesh, He \& Reiner (2016) for electricity poverty in China and Nguyễn \& Hà Dương $(2017,2019)$ for electricity poverty in Vietnam. Finally, multidimensional energy poverty indices were proposed by Nussbaumer, Bazilian, \& Modi (2012), Foster, Tre, \& Wodon (2000) and Pachauri, Mueller, Kemmler, \& Spreng (2004), and the multitier matrix for measuring access to household electricity supply was proposed by Bathia \& Angelou (2015).

In contrast to these objective approaches, the subjective perspective is more straightforward. It defines the quality of energy services by user satisfaction, not in terms of electricity or money quantities measured externally. We argue that concerning Indicator 51, the definition "share of households replying positively" to the question "In the last month, did your consumption of electricity meet the needs of your household?" is as operational as the classical definition "share of population with access to reliable electricity". The belief that objective engineering and economic indicators are more scientific than indicators based on subjective self-assessment is unfounded.

There is prejudice in the opposition between scientific approaches. The subjective definition prescribes a clear way to measure the phenomenon. Humanities and social sciences 
have long integrated the need to include the subjects' voices in their research methods, including subjective opinion surveys. Surveys provide objectively repeatable measurements: Two independent survey companies applying the same method will find similar results.

The objective approach is not as unambiguous as it may seem. Engineering-based indicators also have imprecision and declaration biases. This is true when data are collected from declarative surveys and when data are collected from electricity bills (fraud exists). The concepts of "reliable" and "access" leave room for interpretation. It is unclear whether "access" is the physical connection to the grid or is the economic means to pay for electricity. Furthermore, "reliable" is vague. Is there a threshold of outage minutes per year? As extreme weather can cause a blackout, at which probability is access considered reliable? Do we even have probabilities? Regarding the basic needs approach, to determine the adequacy of someone's habitat objectively, one has to examine its floorplan, building material, insulation, heating, ventilation systems, the local climate and the age of the inhabitants. It is much simpler just to ask.

Leaving it up to respondents to assess the "needs of your household" resolves the central problem of defining a "basic needs" level. Households themselves know best if their electricity needs were met. Multidimensional energy poverty indices rely on normative aggregation methods that are hard to justify, whereas households have the legitimacy to integrate the different aspects of their energy consumption experience. Rebound effects in rural electrification projects show that needs are subjective and relative. Human needs expand with economic development.

Contrary to objective and absolute definitions of basic needs, indicators defined by selfassessed satisfaction of needs can be used at different income levels, within and across countries. Ensuring access to modern energy for all (the SDG 7) does not mean bringing the grid close to every house, as Indicator 51 measures. It means everyone is provided sufficient energy services.

\section{Data and method}

In light of the previous discussion, we use three approaches to examine progress toward SDG 7 in Vietnam. From the engineering point of view, we investigate the access and quantity of electricity consumption. From the economic point of view, we examine the share of electricity in the household budget. From the subjective point of view, we examine customer satisfaction, in the form of the answer to the question, "In the last month, did your consumption of electricity meet the needs of your household?"

The data come from periodic national population surveys: the Household Living Standards Surveys (General Statistics Office, 2019). Conducted by the National Statistics Office in the Ministry of Planning and Investment, the surveys aim to systematically collect basic information about population and housing as a basis for research and for assessing and formulating policy mechanisms, programs, targets and plans for national socio-economic development generally and for the population and housing sectors in particular. The agency is independent of EVN, the national electricity company.

In 2008, the survey had two waves lasting two months each, starting in May and September. In 2014, there were four waves lasting one month each, in March, June, September and December. This reduces the seasonality bias of energy consumption. Households were randomly assigned to the waves. The question on needs met was asked in 2010, 2012 and 2014 only. We did not weigh answers, de-bias, or otherwise adjust the data except by clipping outlying values and dropping missing responses. Clipping does not affect the counts and quantiles, but nonresponses are known to affect survey results. We were not involved in the data collection.

The results we present are subject to systematic and random errors unavoidable in all survey data (Kasprzyk, 2005). We did not attempt to quantify these errors formally, but we 
FREP 1,1

\section{8}

note that in the numbers presented below, the third digit is not policy-relevant. It is meaningful mathematically only. We drew the maps in Figures 1 and 4 without tone intensity correction for province size and province population: They reflect energy poverty levels within a province. Thus, a large gray area does not imply that a large number of people are impacted because provinces in remote mountains are less densely populated than provinces in the river deltas.

\section{The engineering view: is electrification complete?}

Much has changed since Nguyễn \& Lefevre (1996) analyzed household energy demand based on a 1992 survey conducted in four provinces. At that time, $91 \%$ of the energy used by households was for cooking and pig feed. Cooking was mostly with coal and residues; electricity was used by less than $2 \%$ of rural households and $6 \%$ of urban households. Households commonly used kerosene and electricity for lighting. This contrasts with the recent survey by Lê \& Pitts (2019), which showcased air conditioning as the key driver of energy consumption for households living on Vietnam's south-central coast.

Văn Bình Đoàn (2010) described electricity access in Vietnam as follows:

Vietnam has gone through a rapid increase in electrification since 1990, where electrification levels jumped from a pre-policy reform rate of less than $50 \%$ in the late 1980 s-early 1990 s to $77 \%$ by 2001 and $96 \%$ by 2009 . The Electrification Programme driven by the Vietnamese government has resulted in increased access for 82 million people between 1976 and 2009. One million people, primarily in the northern mountainous regions of Vietnam, are currently without access to electricity.

To revisit these numbers in 2018, we used answers to the survey question, "What is the main lighting mean in your household?" which had four options: (1) national-grid electricity; (2) battery or generator or small-scale hydroelectricity; (3) gas, oil lamps of various kinds; and (4) other. Figure 1 shows the percentage of households that did not choose option 1 (national-grid electricity). This is a proxy for the state of electrification during the 2008-2018 period. It shows that the situation in the northern mountainous regions of Vietnam has improved over the last 10 years, but has not been completely resolved. There are still not many roads in these areas. The cost of these grid connections is high compared to the number of households serviced.

Concerning the overall population, the analysis shows that in $2010,96.5 \%$ of households in Vietnam used grid electricity for lighting. This number increased to $98.9 \%$ in 2018 . Our
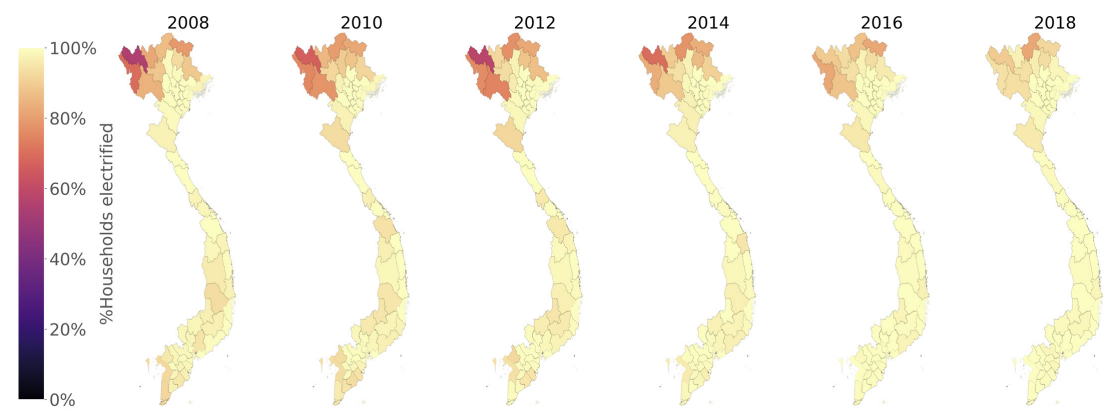

Figure 1.

Progress of electrification
Note(s): The share of households not relying on the national grid for electricity decreased from 2008 to 2018 in most provinces. Limited access to the national electricity grid in rural areas remains only in the northern-most provinces. A high-resolution figure is available as supplementary material 
estimate for 2018 is close to the $99.1 \%$ published in General Statistics Office (2019, p. 500); and consistent with EVN's $(2019$, pp. 14, 19) statement: "EVN provided 100\% of communes, more than $99 \%$ of rural households, and 11/12 districts of islands with electricity access." Considering that the population totals 94.7 million and that households without access are likely to have more members than the national average, we estimate that the number of people without electricity access in Vietnam was still about 1 million in 2018. The number of people without access declined slowly over the period, as Văn Bình Đoàn's description remains relevant. The positive way to see the evolution is that the number of people with access increased as fast as the population, almost 1 million per year.

Figure 2 shows the amount of electricity households declared they had used in the previous month. In 2018, the median electricity consumption was $139 \mathrm{kWh}$ per month and $81 \mathrm{kWh}$ in the first quartile. In other words, that year, out of four Vietnamese households, one used less than $81 \mathrm{kWh}$ per month, and one used between $81 \mathrm{kWh}$ and $139 \mathrm{kWh}$. During the 2010-2018 period, the distribution shifted to the right toward higher quantities. The median electricity consumption per Vietnamese household in the surveyed month increased from $74 \mathrm{kWh}$ to $139 \mathrm{kWh}$ in these eight years.

During that period, the use of electricity by Vietnamese households moved toward a more uniform distribution. As apparent in Supplementary Figure 5, inequality in electricity consumption decreased faster than inequality in income during that period.

\section{The economic view: is electricity affordable for all?}

Figure 3 shows the electricity tariffs in Vietnam from 2004 to 2018. There are many curves because the tariff is an increasing staircase function: The more one consumes electricity, the higher the marginal tariff. In 2010, for example, for electricity consumers paid $600 \mathrm{VND} / \mathrm{kWh}$ for the first $50 \mathrm{kWh}$, then $1004 \mathrm{VND} / \mathrm{kWh}$ from the $51 \mathrm{st} \mathrm{kWh}$ to the 100 th $\mathrm{kWh}$ and so on (see Supplementary Figure 1).

Increasing block tariffs for electricity, water, or gas are popular in many countries because they offer policymakers a tool for addressing equity and efficiency concerns. First, as far as

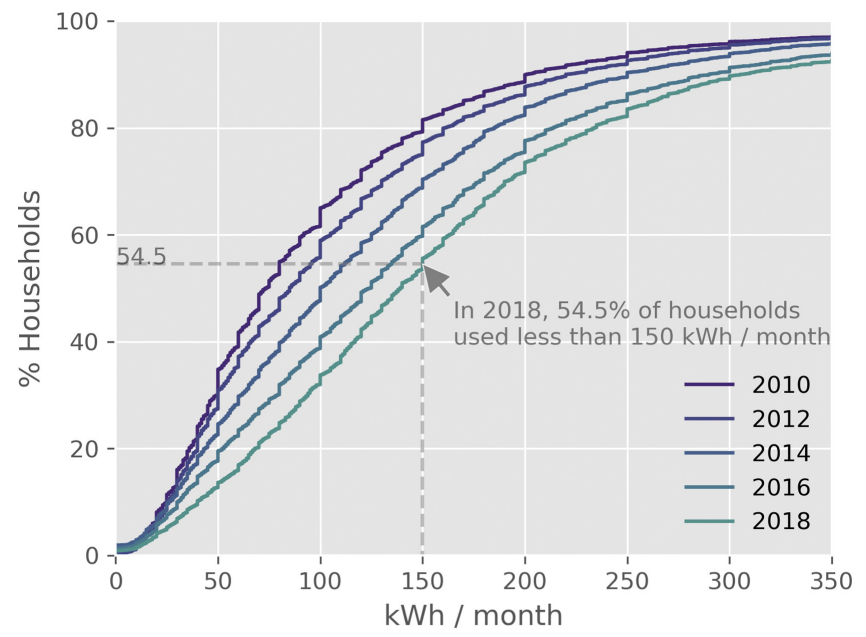

Note(s): The curve moves to the right over time, as households use increasing amounts of electricity
Electricity poverty reduction in Vietnam

\section{政}




\section{FREP 1,1}

Figure 3.

Electricity block tariff for households in Vietnam, in nominal terms (left) and adjusted for inflation (right)
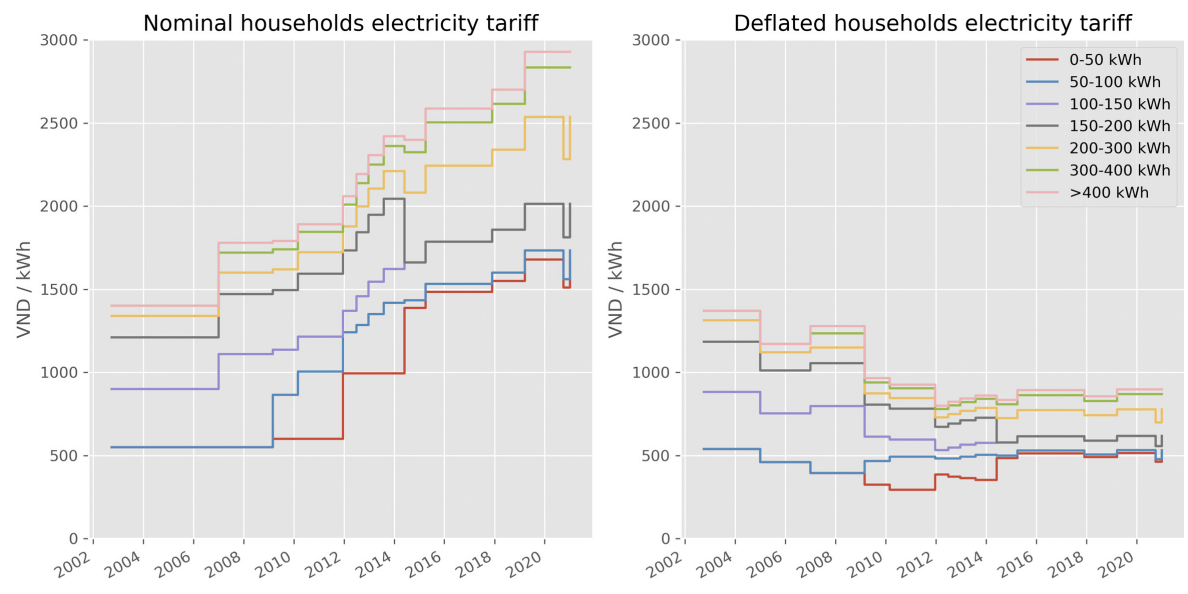

Note(s): The real electricity price for households decreased from 2003 to 2018

power demand correlates with wealth, an increasing block tariff improves equity. It gives poor households access to electricity at a relatively low price. The first block can be provided at a tariff lower than production costs, enacting solidarity between users. Second, an increasing block tariff may improve energy efficiency. It presents higher marginal costs of electricity to households with higher electricity consumption. That tends to reduce wasteful uses and moderate the growth of their electricity demand.

The right panel in Figure 3 shows that the government kept electricity tariffs under control during the high-inflation years after the 2008 global economic crisis (Nguyễn, 2010). This contributed to protecting poorer consumers and mitigated inflation. Tariffs eventually caught up when the inflation cooled down, but in real terms, Vietnamese households faced cheaper electricity bills in 2020 than in 2010.

The average electricity tariff in Vietnam is low compared to other countries. In 2014, for example, it was $0.08 \mathrm{USD} / \mathrm{kWh}$. Among 29 major countries in Asia and the Pacific, only Bhutan, Mongolia and Myanmar had a lower tariff (World Bank, 2020, p. 68).

Table 2 displays the budget effort indicator, defined as the weight of the electricity bill in a household's budget (also Supplementary Figures 2 and 3). Electricity is affordable in Vietnam, meaning that the budget effort remains at a modest level. In 2018, the median household electricity budget effort was $2.4 \%$ of income. This compares favorably with other countries. For example, according to International Energy Consultants (2016):

In the Philippines [...] the average size $(170 \mathrm{kWh} /$ month) household spent an estimated $4.5 \%$ of monthly disposable income on electricity in January 2016 (down from $>6 \%$ in 2012). The average spend of 44 markets surveyed was 3.9\%, ranging from a low of $1.5 \%$ in Taiwan to a high of $8.2 \%$ in Portugal.

Supplementary Figure 4 shows that $95 \%$ of Vietnamese households spent less than $7 \%$ of their income on electricity.

However, Table 2 shows a trend suggesting that the cheap electricity years may not last. The median budget effort was $1.5 \%$ in 2010 as a result of the 2008-2010 electricity price control. After that, the effort increased by 50\% between 2010 and 2018. As households become more affluent over time, it is normal that they consume more, and that their bills increase in nominal and in real terms. We see not only this development but also that electricity expenses have increased faster than income. 
Economists talk about a luxury or a superior good when the fraction of the budget spent purchasing the good increases when the household's income increases. However, this evidence does not imply that electricity is always a luxury or superior good for everybody. First, as shown above, the relative price of electricity declined over the 2010-2020 period, which can explain part of the demand increase. Second, the econometric analysis presented by Nguyễn \& Hà Dương (2019, chapter 6) showed that the electricity consumption of households in lowerincome quantiles is inelastic to income. Electricity is an essential good for poor households.

\section{The subjective view: are electricity needs met?}

The responses to Question 12 on the 2010, 2012 and 2014 VHLSS surveys are summarized in Table 3 ("Has your electricity usage [.. . .] been sufficient to meet needs over the last 30 days?"). The table shows that in 2010, one out of four households in Vietnam declared that their electricity consumption was not sufficient to meet their needs. That ratio dropped to less than $5 \%$ in 2012 and less than $3 \%$ in 2014 .

Figure 4 maps this rapid progress in satisfaction between 2010 and 2012. The subjective indicator shows that during the 2010-2012 period, there was significant progress toward meeting SDG 7. How can we explain it?

A systematic survey error may be present. However, according to the survey documentation, the question's wording was the same in 2010, 2012 and 2014.

Expanded energy access is not the only explanation. There is a correlation between access and satisfaction; see Figures 1 and 4. Satisfaction increased much faster compared to the relatively slow progress of the grid.

Energy-use expectations and behaviors are known to adjust. Could it be that households were more able to meet their needs with what was provided? We believe this effect may work in the opposite direction, given that the equipment levels increased. Regarding households' demand for electricity, the General Statistics Office of Vietnam (2015, p. 26) stated that:

The percentage of households with fixed or mobile telephones reached $85 \%$, the rate of households using a computer was $25.1 \%$, the rate of households using a washing machine reached $30.9 \%$, and the rate of households using refrigerators was $59.0 \%$. All of these were at least twice as high as the

\begin{tabular}{|c|c|c|c|c|c|c|}
\hline Year & 2008 & 2010 & 2012 & 2014 & 2016 & 2018 \\
\hline Households not paying anything & $3.5 \%$ & $3.6 \%$ & $3.2 \%$ & $2.3 \%$ & $1.4 \%$ & $1.1 \%$ \\
\hline $\begin{array}{l}\text { Households paying more than } 6 \% \text { of their income for } \\
\text { electricity bill }\end{array}$ & $2.5 \%$ & $2.3 \%$ & $3.0 \%$ & $5.1 \%$ & $6.2 \%$ & $7.9 \%$ \\
\hline Half of the households pay less than _ $\%$ of income & $1.6 \%$ & $1.5 \%$ & $1.8 \%$ & $2.1 \%$ & $2.3 \%$ & $2.4 \%$ \\
\hline $95 \%$ of the households pay less than _ $\%$ of income & $4.7 \%$ & $4.6 \%$ & $5.2 \%$ & $6.0 \%$ & $6.4 \%$ & $7.0 \%$ \\
\hline
\end{tabular}

Source(s): Authors, from VHLSS data
Electricity poverty reduction in

Vietnam 


\section{FREP 1,1}

\section{2}

Figure 4.

Progress of satisfaction levels
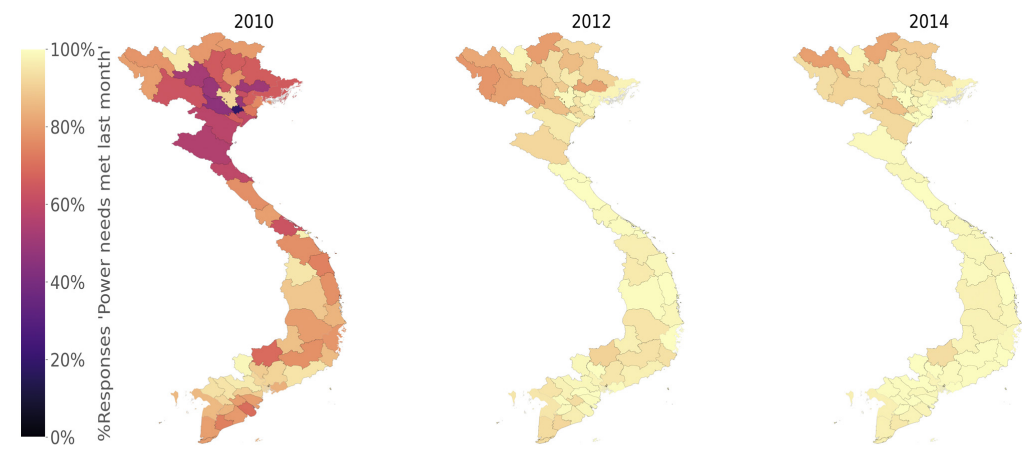

Note(s): The share of households declaring their electricity consumption was not sufficient to meet their needs in the previous month decreased rapidly between 2010 and 2012

indicators in the 2009 Census. In addition, the rate of households using air conditioning stood at $13.3 \%$, nearly three times higher than the rate in the 2009 Census.

We cannot rule out a fluke due to need variations. Energy demand is known to be sensitive to weather, which is random. The weather in 2010 was warmer than in 2012 and 2014. The heatwave could have led to exceptionally high cooling needs and shortages due to low flows to hydropower stations. A small fraction of households had air conditioning at that time, but fans also require electricity. However, we offer a simpler explanation.

We conjecture that satisfaction increased between 2010 and 2012 because the reliability of the electricity supply improved. In 2010, there were many shortages due to delays in adding new coal power plants. After 2010, reserve generation capacity increased, and that improved reliability. According to the IEA (accessed 2021-02-08), the Vietnamese residential sector consumed 31.5 TWh in 2010, 38.4 TWh in 2012 and 45.7 TWh in 2014. The 50\% growth in four years shows there was unsatisfied demand in 2010. Numbers for 2010 are not available, but according to the EVN (2016) annual report, the system average interruption duration index increased from 8077 minutes per customer in 2012 to 3134 minutes in 2014.

The subjective indicator provides an integrated measure of the quality of service. People's impressions are not as much based on averages of physical and economic flows as on extreme events: A power outage during a heatwave or cold wave will be remembered.

\section{Interactions between the three viewpoints}

In section 4, we discussed the engineering viewpoint (access to electricity and quantities consumed). In section 5, we examined the economic viewpoint (tariffs and the weight of the electricity bill in households' budget). In section 6, we discussed the subjective viewpoint (satisfaction of electricity needs). Only that viewpoint allowed us to see the qualitative jump between 2010 and 2012.

In this section, we examine the interactions between the three viewpoints quantitatively. Figure 5 shows the number of respondents of the VHLSS, 2014 who met three different criteria for energy poverty: using less than $30 \mathrm{kWh}$ per month, spending more than $6 \%$ of income on electricity and declaring their electricity consumption did not meet their needs. The first two are objective; the third is subjective. The precise limits for the objective criteria are arbitrary, but the qualitative result does not depend on it: There is little overlap between the three energy poverty indicators. 


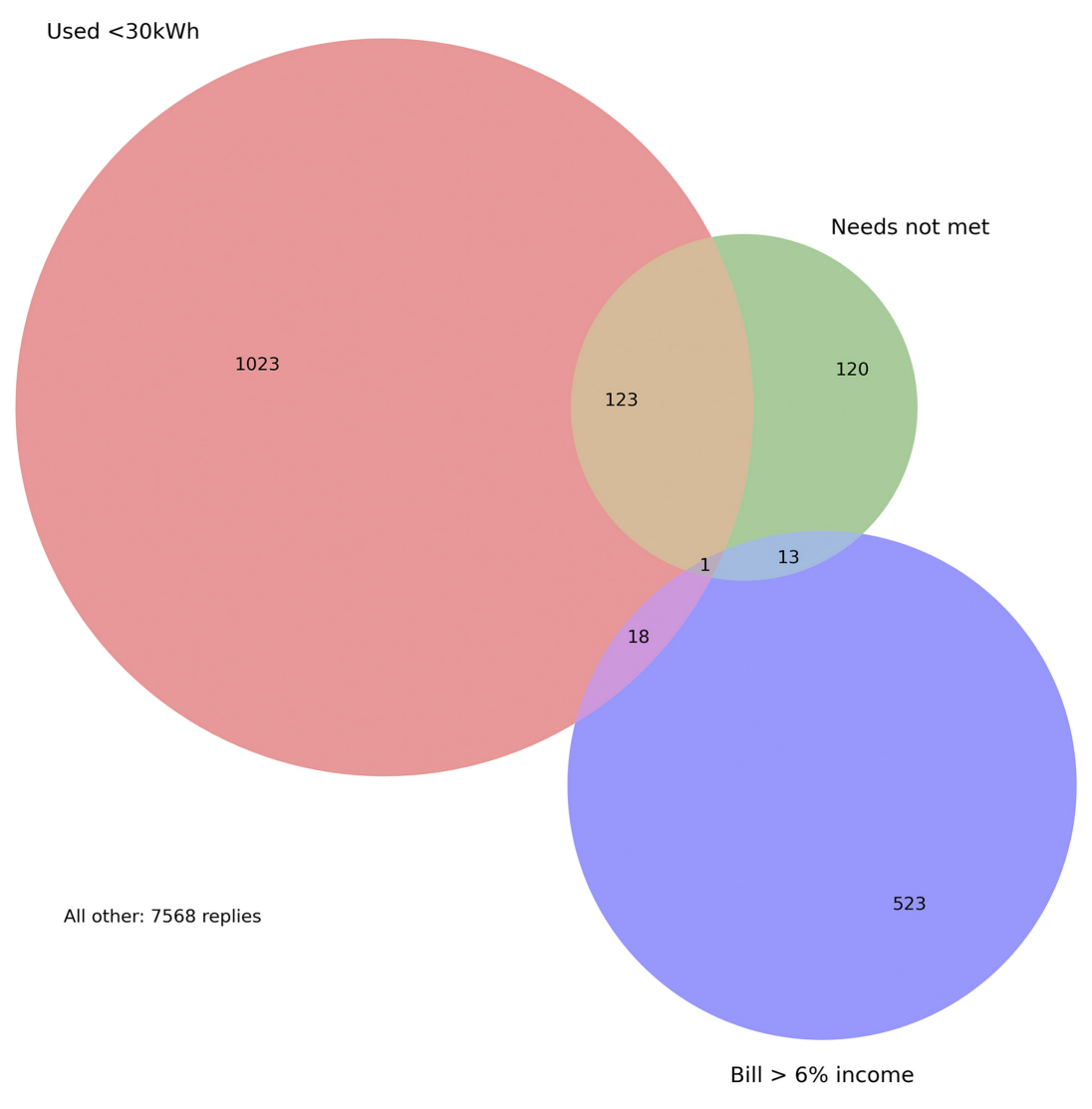

Figure 5.

Interactions between the electricity poverty criteria in VHLSS, 2014

Consider first the interaction between the energy poverty bar idea based on electricity consumption and the subjective indicator of needs not met. Table 4 shows that in 2014, the electricity consumption of households with unsatisfied needs tended to be lower than in the rest of the population. In 2014, half of the households in Vietnam that declared their electricity needs were not met used less than $25 \mathrm{kWh}$ per month.

\begin{tabular}{lcc}
\hline & $\begin{array}{c}\text { All households } \\
(n=9359)\end{array}$ & $\begin{array}{c}\text { Households declaring electricity consumption } \\
\text { did not meet their needs }(n=235)\end{array}$ \\
\hline $\begin{array}{l}\text { Median electricity used in the } \\
\text { last month }\end{array}$ & $100 \mathrm{kWh}$ & $25 \mathrm{kWh}$ \\
$\begin{array}{l}\text { Interquartile range } \\
\text { 5-95th percentile range }\end{array}$ & $52-168 \mathrm{kWh}$ & $0-87 \mathrm{kWh}$ \\
Median effort (ratio electricity & $16-325 \mathrm{kWh}$ & $0-200 \mathrm{kWh}$ \\
bill/budget) & $2.1 \%$ & $0.9 \%$ \\
Interquartile range & $1.3-3.2 \%$ & $0-2.2 \%$ \\
5-95th percentile range & $0.6-6 \%$ & $0-5.7 \%$
\end{tabular}

Source(s): VHLSS (General Statistics Office, 2014)

Table 4.

Households declaring their electricity consumption did not meet their need, compared to the general population 
FREP 1,1

\section{4}

What does $25 \mathrm{kWh}$ per month mean in terms of basic needs? It amounts to about $830 \mathrm{Wh}$ per day. This is more than enough to charge many mobile phones as a phone battery contains about $5 \mathrm{Wh}$. It is also enough for lighting, as a modern light bulb is about $10 \mathrm{~W}$, a few hours per day. A TV and fans can also fit within this energy budget. However, this budget does not include modern comfort appliances. This amount of energy is not sufficient to run an air conditioning unit or refrigerator or provide electric cooking or heating.

Households that declared that their electricity consumption did not meet their needs tend to use little electricity (in 2014), but the converse is not true. Using small quantities of electricity can satisfy needs. In this sample, among the households that used less than $30 \mathrm{kWh}$ of electricity, most did not declare their needs unsatisfied (see Figure 5). This shows that the absolute amount of energy used is not a sufficient indicator to determine satisfaction. The perceived comparison of the energy used with the needs of the household, determined by the appliances it owns, determines sufficiency.

Second, consider the interaction between the high electricity cost ideas based on the share of income devoted to electricity and the subjective indicator. In 2014, about $6 \%$ of Vietnamese households had high electricity costs, defined as an electricity bill larger than $6 \%$ of their income. Survey results show a very small overlap between that population and the households declaring that their needs were not met (see Figure 5). Furthermore, respondents declaring their electricity consumption did not meet their needs tended to spend less on electricity than the general population. The share of income devoted to energy is not a sufficient indicator to determine satisfaction. Vignon (2014) also found a low correlation between objective and subjective energy poverty indicators. Specifically, in France, only $20 \%$ of the households that spent more than $10 \%$ of their income on energy also declared that they felt cold.

Third, the high electricity cost (budget effort $>6 \%$ ) subsample also has very little overlap with the low electricity consumption subsample. This survey confirmed that the high electricity cost definition of energy poverty is problematic, as discussed in section 6 .

\section{Discussion}

In this section, we discuss Vietnam's progress toward SDG 7 and the policy implications for energy poverty. We contextualize the results by comparing them with those of ASEAN countries; refer to International Energy Agency et al. (2020, p. 7) and Roseberry (2020) for comprehensive data on electricity poverty and SDG 7.

Four indicators related to SDG 7 (access to clean, reliable and affordable energy for all) based on VHLSS survey data are summarized in Table 5 . The first row is a proxy for SDSN Indicator 51 discussed in section 6, access to reliable electricity. The next three rows correspond to the three viewpoints discussed in sections 11,14 and 17.

Table 5.

Evolution of performance indicators toward access to clean and affordable energy for all in Vietnam (less is better)

\begin{tabular}{lcccccc}
\hline Year & 2008 & 2010 & 2012 & 2014 & 2016 & 2018 \\
\hline Share of households not using grid electricity for & $4.3 \%$ & $4.7 \%$ & $4.4 \%$ & $3.3 \%$ & $2.0 \%$ & $1.6 \%$ \\
lighting, rural/urban & $0.3 \%$ & $0.3 \%$ & $0.3 \%$ & $0.1 \%$ & $0.1 \%$ & $0.0 \%$ \\
$\begin{array}{l}\text { Share of households declaring less than 30 kWh of } \\
\text { electricity used within the previous 30 days }\end{array}$ & $\mathrm{NA}$ & $12.9 \%$ & $11.9 \%$ & $11.2 \%$ & $8.8 \%$ & $6.2 \%$ \\
$\begin{array}{l}\text { Share of households paying more than 6\% of their } \\
\text { income for electricity }\end{array}$ & $2.5 \%$ & $2.3 \%$ & $3.0 \%$ & $5.1 \%$ & $6.2 \%$ & $7.9 \%$ \\
$\begin{array}{l}\text { Share of households declaring their electricity } \\
\text { consumption within the previous 30 days did not meet } \\
\text { their needs }\end{array}$ & $\mathrm{NA}$ & $24.0 \%$ & $4.7 \%$ & $2.7 \%$ & $\mathrm{NA}$ & $\mathrm{NA}$ \\
$\begin{array}{l}\text { Source(s): Authors, VHLSS data } \\
\text { Sours }\end{array}$ & & & & & & \\
\hline
\end{tabular}


The first row shows that Vietnam has mostly achieved access to clean energy for all of SDG 7. Vietnam has a lower-middle-income economy. According to World Development Indicators (World Bank, accessed 2021-02-18, statistics for 2018), 86.3\% of the population had access to electricity in that country group. Vietnam scores above its peers. Its access indicator compares with that of upper-middle-income countries, where $99.4 \%$ of the population had access (World Bank, op. cit.). Historically within ASEAN, Vietnam achieved electrification after Brunei Darussalam, Malaysia, Singapore and Thailand, but before the Philippines, Indonesia and the Lao PDR (Gu, Yan, \& Nuki, 2020). As of 2019, Cambodia and Myanmar had yet to reach a $95 \%$ electrification rate.

Based on electricity consumption per capita, Gu, Yan, \& Nuki (2020) classified ASEAN member states into four groups. The first is Singapore, Thailand and Brunei Darussalam. Vietnam is in the second group, with Malaysia and Indonesia. The third group includes Lao PDR and the Philippines. The fourth group is Cambodia and Myanmar.

The Philippines and Indonesia have higher incomes than Vietnam but numerous isolated islands, making electrification more difficult. Lao PDR is a continental country well-endowed in hydroelectric resources and income per capita comparable to Vietnam's. Nevertheless, Laos PR's electricity consumption per capita is much lower, perhaps because it has a higher percentage of rural households living in mountain areas. Cambodia and Myanmar are behind Vietnam in electricity access because they have lower income per capita. The same logic applies when comparing Vietnam with Brunei Darussalam, Malaysia, Singapore and Thailand.

That second row shows the share of households using less than $30 \mathrm{kWh}$ per month. The percentage of households below the electricity poverty line is an energy poverty indicator. We chose $30 \mathrm{kWh}$ because it is the amount subsidized in official Vietnamese policies. However, the group covers diverse situations, the first three levels in Bathia \& Angelou's (2015) multitier matrix for measuring household electricity consumption. The less than $30 \mathrm{kWh}$ group ranges from households without any electricity access to households using about 1000 Wh per day, which is enough for lighting, charging phones and running fans and television. By 2018, this under-30 kWh/month group comprised less than $7 \%$ of households, declining by about one percentage point per year during the period.

Row three shows the share of households spending less than $6 \%$ of their income on electricity. The conclusion that the burden is increasing fast does not depend on the precise $6 \%$ value, as Supplementary Figure 2 shows. Do rows two and three confirm that "[e]lectricity poverty decreased but electricity-cost poverty increased” (Nguyễn Hà Dương, 2019)? Spending more on electricity is not necessarily a welfare loss. Electricity can substitute other forms of energy, reducing their cost, particularly for rural and less wealthy households, which were still a majority of the population at the start of the sample period. Biomass use decreased at the same time electricity consumption increased. According to the International Energy Agency (Data and statistics, accessed 2021-02-10), in 2018, the total final energy consumption by the Vietnamese residential sector (households) was 10,059 ktoe, of which 5352 ktoe ( $52 \%$ ) was as electricity and 2213 ktoe $(22 \%)$ was as biofuel and waste. In 2008 , the total was 15,110 ktoe, of which electricity was 2241 ktoe (15\%) and biomass 11,086 ktoe (73\%). Most of the costs of using biomass energy are non-market. It would be difficult to quantify the welfare gains of using an electric rice cooker over a traditional wood stove, but given a choice, many households choose the first option.

Electricity is affordable for most households, but energy poverty remains for many. According to the General Statistics Office (2019, p. 435), air conditioner ownership per 100 households increased from 5.50 to 35.1 between 2008 and 2018. For urban areas, the ratio increased from 17.3 to 70.1 . The statistic increased only from 0.1 to 3.3 air conditioners per 100 households for the lowest income quintile. Not being able to protect against extreme heat fits with the first definition of energy poverty presented in section 6 . 
FREP 1,1

\section{6}

The barrier to air conditioning is not only capital but also operating costs. During the 2020 summer heatwave, several mass media raised the issue of cooling affordability for poor households (Lê, 2020; Thương \& Hà, 2020). The monthly income per capita in 2018 for the first quintile was VND 923,000, about 41 USD (General Statistics Office, 2019, p. 22). For poor households, each kilowatt-hour counts. Using $1 \mathrm{~kW}$ for 100 hours in a month costs about VND 200,000 at the third tariff block. To compound the problem, many landlords charge high rates for electricity. If the government gave appliances for free, there would still be energy poverty in the sense of the fourth criterion discussed in section 2.

The fourth (bottom) row in the table is about satisfaction, the share of households stating that their electricity consumption did not meet their needs the previous month. We regret that the 2016 and 2018 household surveys did not measure this indicator. As a regulated monopoly provides electricity, it remains useful that national statistical offices provide the government with independent performance indicators. National electricity policies have many objectives. Goals for the energy sector as a whole include independence and sustainability. Objectives for households include universal access to electricity, affordable tariffs and satisfying quality of service. We believe that these three objectives require different indicators. Energy poverty must be measured and discussed with engineering, economic and subjective data. The subjective energy indicator-designed from surveys asking people whether they had enough electricity to meet their households' needs - provides essential customer satisfaction feedback that cannot be obtained by looking only at kilowatthours and money flows.

For policymaking, the discussions on SDG 7 and energy poverty indicators lead to operational criteria defining which households should be eligible for support. In section 7 , we showed that the three different approaches point to different households. We argue that the subjective indicator is the most theoretically satisfying measure of progress toward SDG 7. However, for identifying which households should receive money, subjective declarative criteria are challenging to trust. Furthermore, the high electricity cost budget effort indicator has problems. Three approaches remain operational for defining households eligible for electricity subsidies: (1) low income, (2) low electricity consumption, or (3) both. The Vietnamese support scheme uses option c. A household with an income poverty certificate could get a subsidy of 30,000 VND/household/month if it consumed less than $50 \mathrm{kWh}$.

The VHLSS, 2014 survey explicitly asked questions about electricity subsidies and poverty certificates. Figure 6 shows how the subsidy mechanism performed. Threequarters of poor respondents declared they received the electricity subsidy. The figure shows that only $37 \%$ of households using less than $30 \mathrm{kWh}$ received the subsidy. The reason is that most of those households do not have a poverty certificate. Finally, only $23 \%$ of households that declared their electricity needs were not met received a subsidy. The subsidy mechanism worked more to alleviate poverty (SDG 1) than to satisfy electricity needs (SDG 7).

Figure 6.

Overlap between households receiving electricity subsidy and subsamples of households matching different electricity poverty criteria in the 2014 VHLSS
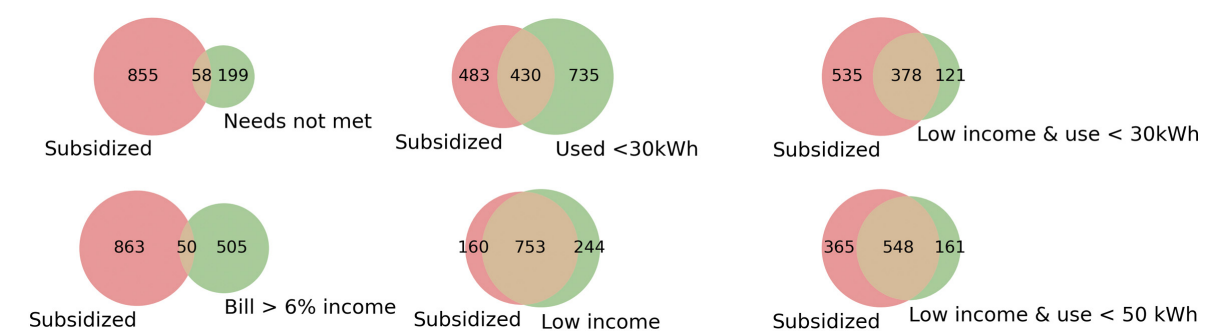


\section{Summary and concluding remarks}

Engineering and econometric objectivist approaches dominate the literature on sustainability monitoring. Out of 232 SDG indicators, only two are subjective (10.3.1 and 16.7.2). The case of Vietnam from 2008 to 2018 shows that subjective and objective energy poverty indicators can tell different sides of the story. In 2010, the fraction of households with access to electricity was higher than $96 \%$, but more than $24 \%$ of households declared their electricity consumption did not meet their needs. Since 2014, the satisfaction rate has been more than $97 \%$, even if $25 \%$ of the households used less than $50 \mathrm{kWh} / \mathrm{month}$.

The subjective measure of energy poverty could be handy for macro-scale international comparisons. The share of households satisfied with their electricity service may be a more informative political indicator than the electrification rate. To target households eligible for energy subsidies, income and electricity consumption indicators may be more operational than personal declarations at the micro-scale. That may explain why the Vietnamese electricity subsidy works more to alleviate economic poverty than to satisfy energy needs.

The three perspectives we explored in this paper converge to indicate that Vietnam progressed very close to SDG 7 (affordable and clean energy for all) over the 2008-2018 period, and that electricity poverty is not an acute social issue in 2018. (1) Vietnam achieved nearly universal access to electricity. The expansion of the grid matched the demographic expansion. To bring electricity to all, the electricity grid increase should exceed the population increase (World Bank Group and International Energy Agency, 2013). About 1 million people lack access to the electricity grid, mostly in remote areas in the northern mountains. (2) The quality of service, defined as customer satisfaction, has improved to a high level. Between 2010 and 2014, the share of households declaring that their electricity consumption did not meet their need dropped from $24 \%$ to $2.7 \%$. (3) Inequalities in electricity consumption among Vietnamese households decreased during the 2008-2018 period. Inequalities in electricity consumption are not greater than inequalities in income, contrary to Son \& Yoon's (2020) findings for the 1993-2004 period. (4) Electricity is affordable in Vietnam. The electricity tariffs declined in real terms during the last 10 years. They are lower than in other ASEAN countries, and households spend a smaller share of their budget on electricity.

As electricity consumption increases, the cost of electricity weights in the budget of Vietnamese households is rising. Raising the price of electricity further may be necessary at some point to pay for imported fuels and for financial investment in capital-intensive solar and wind power plants, and to reinforce and modernize the grid. As long as the government regulates retail tariffs, it retains the possibility to share the costs between the different categories of electricity consumers. For example, the government could charge households less and industrial, commercial and institutional consumers more. The increasing block tariff is not the only tool for protecting households from electricity poverty.

\section{References}

Asian Development Bank (2011). Energy for all: Viet Nam's success in increasing access to energy through rural electrification, Available from: https:/think-asia.org/bitstream/handle/11540/963/ rural-electrification-vie.pdf (accessed 22 June 2021).

Atkinson, A.B. (1987). "Poverty". In Name, X. (Ed.), The New Palgrave Dictionary of Economics, London: Palgrave Macmillan, 1-9, doi: 10.1057/978-1-349-95121-5_1597-1.

Baltruszewicz, M., Steinberger, J. K., Ivanova, D., Brand-Correa, L. I., Paavola, J., \& Owen, A. (2021). Household final energy footprints in Nepal, Vietnam and Zambia: Composition, inequality and links to well-being. Environmental Research Letters, 16(2), 025011, doi: 10.1088/1748-9326/ abd588.

Electricity poverty reduction in Vietnam 
FREP 1,1

Bathia, M., \& Angelou, N. (2015). Beyond connections: Energy access redefined. ESMAP Technical Report 008/15. Washington, DC: World Bank. Available from: http://hdl.handle.net/10986/24368 (accessed 22 June 2021).

Bravo, V., Mendoza, G.G., Legisa, J., Suárez, C.E., \& Zyngierman, I. (1983). A first approach to defining basic energy needs. Tokyo: United Nations University.

Department of Trade and Industry (2007). Fuel poverty. The National Archives. 6 March, Available from: http://webarchive.nationalarchives.gov.uk/20070603164901/http://www.dti.gov.uk/ energy/fuel-poverty/index.html (accessed 22 June 2021).

EVN (2019). Vietnam electricity annual report 2018. Vietnam Electricity (EVN). Available from: https:// www.evn.com.vn/userfile/User/tcd1/files/2019/8/EVNAnnualReport2018(1).pdf (accessed 22 June 2021).

Foster, V., Tre, J.P., \& Wodon, Q. (2000). Energy prices, energy efficiency, and fuel poverty. unpublished paper. Washington, DC: Latin America and Caribbean Regional Studies Program The World Bank. Available from: http://www.mediaterre.org/docactu,bWF4aW0vZG9jcy9wZTE=,1.pdf (accessed 22 June 2021).

General Statistics Office (2019). Result of the Viet Nam household living Standards survey 2018. Ha Noi, Viet Nam: Statistical Publishing House. Available from: https://www.gso.gov.vn/en/dataand-statistics/2020/05/result-of-the-vietnam-household-living-standards-survey-2018/ (accessed 22 June 2021).

General Statistics Office of Vietnam (2015). The 1/4/2014 Viet Nam intercensal population and housing survey: Major findings. City, Vietnam: Ministry of Planning and Investment. Available from: https://www.gso.gov.vn/en/data-and-statistics/2019/05/the-1-4-2014-viet-nam-intercensalpopulation-and-housing-survey-major-findings/ (accessed 22 June 2021).

Gu, H., Yan, B., \& Nuki, A.U. (2020). Practical experience and prospects for energy accessibility in ASEAN. Jakarta: ASEAN Centre for Energy and China Renewable Energy Engineering Institute. Available from: https://aseanenergy.org/practical-experience-and-prospects-forelectricity-accessibility-in-asean/(accessed 22 June 2021).

He, X., \& Reiner, D. (2016). Electricity demand and basic needs: Empirical evidence from China's households, Energy Policy, 90(March), 212-221, doi: 10.1016/j.enpol.2015.12.033.

Hills, J. (2012). Getting the Measure of fuel poverty: Final Report of the fuel poverty review. CASE report 72. Center for Analysis of Social Exclusion. Available from: http://eprints.lse.ac.uk/43153 (accessed 22 June 2021).

International Energy Consultants (2016). Regional/Global comparison of retail electricity tariffs executive summary, Available from: http://corporate-downloadables-tips.s3.amazonaws.com/ 1478573661.68b4d11ba9cb3ccb30e91c6edd66b6c9.pdf (accessed 22 June 2021).

International Energy Agency, International Renewable Energy Agency, United Nations Statistics Division and World Health Organization (2020). Tracking SDG 7. The energy progress report. Washington, DC: The World Bank, the International Energy Agency, the International Renewable Energy Agency, The United Nations Statistics Division and the World Health Organization. Available from: https://trackingsdg7.esmap.org/(accessed 22 June 2021).

Kasprzyk, D. (2005). "Measurement error in household surveys: Sources and measurement", chapter IX, household sample Surveys in Developing and transition countries, 171-198). New York, NY: United Nations Publications. Available from: https://unstats.un.org/unsd/hhsurveys/ (accessed 22 June 2021).

Khandker, S.R., Barnes, D.F., \& Samad, H.A. (2012). Are the energy poor also income poor? Evidence from India. Energy Policy, 47(August), 1-12, doi: 10.1016/j.enpol.2012.02.028.

Lê, B. (2020). Nghịch Cảnh Mùa Nắng nóng, Có Điều Hòa Vẫn Không Dám Dùng, Giadinh.Net.Vn, 7(July). Available from: https://giadinh.net.vn/news-20200706171746705.htm (accessed 22 June 2021). 
Lê, V.P. (2020). Electricity price and residential electricity demand in Vietnam. Environmental Economics and Policy Studies(February), doi: 10.1007/s10018-020-00267-6.

Lê, V.T., \& Pitts, A. (2019). A survey on electrical appliance use and energy consumption in Vietnamese households: Case study of Tuy Hoa city. Energy and Buildings, 197(August), 229 241, doi: 10.1016/j.enbuild.2019.05.051.

Li, K., Pan, S.Y., \& Wei, Y.M. (2015). A bibliometric analysis of energy poverty research: Results from SCI-E/SSCI databases. Interntional Journal of Global Energy Issues, 38(4-6), 357-372, doi: 10. 1504/IJGEI.2015.070263.

Nguyễn, M.P. (2010). Preventing power tariffs from stoking inflation. The Saigon Times, 25(February). Available from: http://english.thesaigontimes.vn/8896/Preventing-Power-Tariffs-From-StokingInflation.html (accessed 25 November 2016).

Nguyễn, A.T., \& Lefevre, T. (1996). Analysis of household energy demand in Vietnam. Energy Policy, 24(12), 1089-1099, doi: 10.1016/S0301-4215(97)80003-6.

Nguyễn, H.S., \& Hà Dương, M. (2017). Is electricity affordable and reliable for all in Vietnam?. In The tenth Vietnam Economist Annual Meeting (VEAM 2017). Ho Chi Minh City.

Nguyễn, H.S., \& Hà Dương, M. (2019). Income and electricity poverty in Vietnam 2012-2016. In The 11th Vietnam Economists Annual Meeting (VEAM 2019). Da Lat.

Nguyễn, T.T., Nguyễn, T.T., Hoang, V.N., Wilson, C., \& Managi, S. (2019). Energy transition, poverty and inequality in Vietnam. Energy Policy, 132(September), 536-548, doi: 10.1016/j.enpol.2019. 06.001 .

Nussbaumer, P., Bazilian, M., \& Modi, V. (2012). Measuring energy poverty: Focusing on what matters. Renewable and Sustainable Energy Reviews, 16(1), 231-243, doi: 10.1016/j.rser.2011. 07.150 .

Observatoire National de la Précarité Energétique (2016). Caractériser le phénomène et le mesurer, Available from: http://www.onpe.org/definition_indicateurs/definition_des_indicateurs (accessed 22 June 2021).

Pachauri, S., Mueller, A., Kemmler, A., \& Spreng, D. (2004). On measuring energy poverty in indian households. World Development, 32(12), 2083-2104, doi: 10.1016/j.worlddev.2004.08.005.

Roseberry, K. (2020). Regional energy trends report 2020. Tracking SDG7 in the ASEAN region, united nations publication ST/ESCAP/2921, sales no. E.21.II.F.2. Bangkok: United Nations Economic and Social Commission for Asia and the Pacific (ESCAP), and ASEAN Centre for Energy (ACE). Available from: https://www.unescap.org/publications/regional-energy-trends-report2020-tracking-sdg-7-asean-region (accessed 22 June 2021).

Son, H., \& Yoon, S. (2020). Reducing energy poverty: Characteristics of household electricity use in Vietnam. Energy for Sustainable Development, 59, 62-70, doi: 10.1016/j.esd.2020.08.007.

Sovacool, B.K., Mukherjee, I., Drupady, I.M., \& D'Agostino, A.L. (2011). Evaluating energy security performance from 1990 to 2010 for eighteen countries. Energy, 36(10), 5846-5853, doi: 10.1016/j. energy.2011.08.040.

Sustainable Development Solutions Network (2015). Indicators and a monitoring framework for the sustainable development goals. Leadership Council of the Sustainable Development Solutions Network. Available from: https://resources.unsdsn.org/indicators-and-a-monitoring-frameworkfor-sustainable-development-goals-launching-a-data-revolution-for-the-sdgs (accessed 22 June 2021).

Thương, M., \& Hà, T. (2020). Nắng nóng đỉnh điểm vẫn không dám bật quạt ở xóm ngụ cư nghèo [Poor neighborhood did not dare to turn on fans at the peak of heatwave], Available from: https://tuoitre.vn/news-20200610134010987.htm (accessed 22 June 2021).

Vignon, J. (2014). Premier rapport de l'ONPE: Définitions et indicateurs. Les Notes de l'ONPE Observatoire National de La Précarité Energétique, 4, 1-6. Available from: http://onpe.org/sites/ default/files/pdf/documents/notes_observatoire/note_ndeg4f4.pdf (accessed 9 July 2021).

Electricity poverty reduction in Vietnam 
FREP

1,1

World Bank (2020). Infrastructure in Asia and the pacific. Washington, DC: World Bank, doi: 10. $1596 / 34228$.

World Bank Group and International Energy Agency (2013). SE4ALL global tracking framework, Available from: https:/www.worldbank.org/en/topic/energy/publication/Global-TrackingFramework-Report (accessed 22 June 2021).

Đoàn, V.B. (2010). Vietnam rural electrification Programme, Available from: http://energy-access. gnesd.org/cases/34-vietnam-rural-electrification-programme.html (accessed 22 June 2021).

\section{Supplementary material.}

Supplementary material is available online for this article.

\section{Corresponding author}

Minh Ha-Duong can be contacted at: haduong@centre-cired.fr

For instructions on how to order reprints of this article, please visit our website: www.emeraldgrouppublishing.com/licensing/reprints.htm Or contact us for further details: permissions@emeraldinsight.com 